\title{
Post-populism in Latin America: On Venezuela after Chávez
}

\author{
Manuel Anselmi ${ }^{1}$
}

Received: 14 April 2017/Accepted: 3 June 2017/Published online: 3 July 2017

(C) Fudan University and Springer Nature Singapore Pte Ltd. 2017

\begin{abstract}
After the death of president Hugo Rafael Chávez Frías, Venezuela represents a very interesting and unique case of institutionalized populist system. In this article, I will attempt to explain some analytical elements by which we may speak of an institutionalized post-populist condition. It is interesting to understand why the populist Chavist system continues to endure, even if with difficulty, in spite of many unfavourable factors like: the death of a charismatic leader and the presence of a weak leadership; and unfavourable and adverse geopolitical and geoeconomical conditions, especially when compared with those of the initial phase of ascent and prosperity. The objective of this article is to study in its complexity the typicality of the post charismatic phase of Venezuela's system and present a case study of the post-populist condition to be able to compare it in a global and comparative perspective.
\end{abstract}

Keywords Venezuelan politics $\cdot$ Chavism $\cdot$ Political polarization · Political leadership · Collateral institutionality

\section{Introduction}

The purpose of this article is to analyse some elements of the social and political condition of Venezuela today, 4 years after Chávez's death in March 2013 (Carroll 2013). The aim will be to describe some fundamental aspects of a post-populist dimension, characterized by the disappearance of the leader and founder of the populist movement, in an attempt to draw a balance of the transformations that this

Manuel Anselmi

anselmimanuel@gmail.com

1 Assistant Professor of Political Sociology at University of Perugia, Perugia, Italy 
movement has produced on the political structures of democracy and Venezuelan public opinion.

Very often, the study of the populist phenomenon focuses on its emerging phases, therefore, populisms are frequently identified with movements. On the contrary, many of the progressive neo-populisms of the Latin American Left, such as Morales in Bolivia and Correa in Ecuador, represent cases of highly institutionalized populisms that have become forms of government and have profoundly altered the institutional system of the state in which they are born. Among them, the Venezuelan case must be seen as a highly institutionalized populist government, but without a charismatic leader pursuing its goal of totalitarian ideological hegemony, and with a very strong opposition that has assumed total refusal of democratic dialectics. In addition, there is a strongly polarized public sphere in which the political opponent is seen by each of the two parties as an enemy to be eliminated and not recognized by any political legitimacy.

Therefore, a reflection on the current Venezuelan political crisis must be the balance of a democratic system in which a populist force has implemented a plebiscite transformation of liberal institutions, thus, from a liberal point of view, it can only be considered a soft authoritarianism regime, or as Corrales and Hidalgo called it: a hybrid regime. (Corrales and Hidalgo 2013).

The Venezuelan political situation has completely changed both in its internal conditions and in its geopolitical relationships more than these years following the death of President Hugo Chávez and election of his designated heir, Nicolás Maduro Moros. Although the Bolivarian government professes to continue its government consistent with the style of its founder; the material conditions, the balance of power and the scenarios have completely altered.

This is in fact a new phase of the Chavist system which, however, continues to remain the prevailing trend in the political scene of the country. There is a growing economic crisis worsened by the current low price of oil with respect to the early years of the first Bolivarian governments and an ever active opposition in the streets, which is still divided and disorganized. Add to this Maduro's leadership, which is evidently weaker and less charismatic than Chávez's, which has often been the object of criticism on the part of the Chavists themselves. Even on the international front the situation has changed completely. The period of the great rise of Pan-South American leadership with the spread of "Left turn" in all of the countries of the area and characterized by the affirmation of many progressive forces from the Kirchners in Argentina, to Lula and Dilma in Brazil, to Correa in Ecuador, to cite only a few, has come to an end. Today some of these countries are experiencing a period of economic and institutional difficulty, others have taken a less ideological stance, adopting for a more reformist and pragmatic, rather than radical, method.

Thus we wonder if it is possible to evaluate these 2 years of post Chávez government. How might we take stock of this political heritage?

Answering these questions may be too great an undertaking both for this article and for the expertise of the author. However, it is more useful on the level of scientific analysis to analyse some structural dimensions that have undergone a transformation in the political system in the last 2 years. At this time and place, I will limit myself to presenting some questions for evaluating the Venezuelan 
democratic system on the basis of political factors and criteria tied to the qualities of democracy (Diamond and Morlino 2005).

It will be easier this way to have more objective elements for a full evaluation of the evolution of the Chavist phenomenon and also gives us useful cause for reflection on the Venezuelan process of democratization in general and on what it represents and will represent for an analysis of democratic phenomena in a global and comparative perspective.

Particular attention will be given to the theme of populism. Indeed, an evident characteristic of the present day Venezuelan political situation that must not be neglected is that it represents a kind of "orphan" populism where a system, a movement and government leanings that were invented by a founding populist leader continue to exist after his death. This condition of a highly populist political system that persists and that has profoundly altered the operation of democratic institutions entails a series of very interesting reflections on the processes of democratization. In effect, as some scholars have noted (Diamond and Regimes 2002), Venezuela represents an emblematic case of hybrid regime, that is to say a system that cannot be called a fully democratic regime because certain minimal conditions necessary for the definition of democracy have not been met. These kinds of considerations open a perspective for analysis with respect to the fact that Venezuela may be considered as a very interesting critical case of the process of democratization. The distinctiveness and rarity lie in the fact that a highly populist dynamic has altered a democratic regime creating a much discussed form of soft authoritarianism, profoundly changing the operation of the country's liberal democratic system.

This article proposes to consider some structural changes of the Venezuelan system from Chávez to Maduro that, according to me, may be useful for making a general appraisal of the evolution of this Latin American political experiment.

In particular, after giving a summary of the parable of Chavist populism in the Latin American context and pointing to the decline of the Rule of Law, I will focus on the analysis of some elements of the post-populist Venezuelan condition: political polarization, collateral institutionality and the rooting of Chavist forces.

\section{Chávez's Populism in the Latin American Context}

Latin America is perhaps the geographical macro-area that has registered the highest prevalence of populisms in contemporary history. From the rise of Perón, the populist option has remained a defining character of Latin American politics (De La Torre and Arnson 2013).

From a historiography and taxonomy point of view, two phases in Latin American populism can be identified: a first one was represented by the classic twentieth century populism, which included Perón as well as Getulio Vargas in Brazil and Gaitan in Colombia, among others; a second phase which started at the end of the 1990s with it's appearance and was linked to the spread of progressive political powers in the whole subcontinent, most of whom became institutionalized and remained in power for over 10 years. This group included Lula in Brazil in 
2002 and then Roussef in 2010; Kirchner in Argentina in 2003; Morales in Bolivia in 2005; Correa in Ecuador in 2006 (Conniff 1982, 2012; Mudde and Kaltwasser 2014).

This political period has been labelled the Left Turn, due to the socialist traits of its governments, after decades of exclusion (Cameron and Hershberg 2010).

Two general factors are worth noting when analysing the rise of the Left Turn populisms: a geopolitical one and an economic-political one.

From a geopolitical point of view, the global political context where these new left-wing forces took hold was the end of the Cold War and Soviet socialism. The fact that new socialist forms reappeared exactly when socialism had ended in most of the world might seem paradoxical. The reason behind it is that, during the cold war, the anti-communist and anti-socialist control on the part of the US had blocked, in legitimate and not so legitimate ways, the spread of progressive forces that were not social-democratic or strongly pro-American. Furthermore, since the late 1990s, but even more so after the attack at the Twin Towers in 2001, US attention has focused mainly on the Middle East and the Islamic world.

From an economic and political point of view, the Left Turn parties emerged and organized towards the end of the 1980s and during the 1990s, as a political reaction to the social difficulties created by the neo-liberal policies implemented in those years by conservative governments. Privatizations, economic crises, drastic cuts in the welfare state, were all factors that contributed to a reorganization of social forces, who all shared the political aim of posing an alternative to liberalism. As a reaction, the Left Turn neo-populisms developed a potent discourse of consensus based on social and political inclusion, which would become the main argument used by some left-wing analysts like Ernesto Laclau for an overall re-evaluation of populism, in their view bearer of highly democratizing aspects. However, the Left Turn represented a parenthesis which is gradually coming to an end, with the return to a new neo-liberal phase. More than Chávez's death in 2013, what marked the resurgence of the right was the election of a liberal candidate in Argentina in 2015, soon matched by the arrival of the Brazilian neo-president Temer, following a controversial impeachment case which deposed Dilma Rousseff in 2016.

From a socio-political point of view, Venezuela represents a very interesting case of populism, due to the complexity of its analysis.

The rise of Hugo Chávez marked the beginning of a turn in Latin American politics. It is both paradigmatic and sui generis: paradigmatic as many of its traits will later be found in other countries, yet sui generis, as its institutional development and the social and political crisis turned it into one of the most radical cases of all. Furthermore, Chavismo, more than any other phenomena, developed a widespread activity of promoting progressive values in a perspective of pan-South Americanism (Hawkins 2010; Anselmi 2013).

A full understanding of Venezuelan Chavismo must take into account the long critical phase that preceded it. From the end of the 1970s and for the whole of the 1980s, Venezuelan society experienced a gradual process of impoverishment and decadence, which manifested itself in an exponential increase in poverty, criminality, and above all social polarization due to the squeeze of the middle class. This growing instability undermined the political and social system that had 
been established since the mid-1950s following the expulsion of the dictator Pérez Jiménez, and that was characterized by alternating power from two parties-centreleft and centre right - and the exclusion of Marxist forces from Parliament. This led to a series of violent social protests that culminated in the 1989 Caracazo, and a period of strong political uncertainty, exasperated by a growing economic crisis. In 1992 a group of army officials attempted a coup, confiding in popular support, which, however, failed and ended with the rebels' imprisonment. Colonel Hugo Rafael Chávez Frías was a leading figure among the rebels. After being released from prison thanks to an amnesty, he started a political propaganda activity which culminated his victory in the 1998 presidential elections. Establishing a direct link to the 1950s revolutionary Bolivarianism, Chávez promoted a Creole socialism (Rouquié 2000, 230) which he labelled 'twenty-first century Socialism', based on the exaltation of direct democracy, citizens' participation, mass social investments aimed at the inclusion of disadvantage classes, and a radical anti-capitalism, linked to an explicit anti-US stand and a strong pan-South American ideal. From its first government, Chavismo represented a highly institutionalized form of populism, which was able to turn the strong social polarization into an incredibly serious political polarization. The constitutional reform that Chávez implemented in 1999 deeply transformed the liberally oriented political system in favour of a strongly plebiscitarian system. Chávez also represented one of the first cases of Latin American telepopulism, as he made mass use of the media to cultivate his own personal consensus and spread the ideas of revolutionary Bolivarism. His TV programme Alò Presidente, during which he used to comment national and international political events and directly answer citizens' calls, was renowned.

Despite the indisputable social successes of its first years, especially in eradicating poverty and illiteracy, the Venezuelan political system started to develop a gradual instability, partly due to the growing conflicts with the opposition, which increased after the 2002 anti-Chávez coup, and partly due to ill advised economic policies that generated an unprecedented recession. Three years after Chávez's death, in an extraordinary situation that could be defined as post-populism, his party, led by his successor Nicolas Maduro, continues to rule despite growing consensus for the opposition, which, in addition to holding a bigger presence in Parliament, is leading a permanent strategy of periodic social protests.

In this phase of crisis and decline, Venezuela represents a particularly interesting example for the evaluation of a populism in government and one that has managed to mould the state form in a populist vein. For these reasons, liberal analysts have criticized the Chavista experience as a process of democratic involution and defined Venezuela a form of soft authoritarianism, more precisely a 'hybrid regime' (Corrales and Hidalgo 2013). This term indicates a democracy which has lost one or more basic requisites, yet cannot be considered as full-blown authoritarianism, as it maintains other elements of democracy. In particular, the autocratic tendencies of the presidential role; numerous cases of penal populism, both in the systematic use of impunity for the lower classes to maintain political consensus, and in influencing judges' activity; the almost ritual use of elections to stress the direct and plebiscitarian character of his consensus and an almost absolute mandate; these are 
all elements that have de-intermediated the Venezuelan representative political system, dissolving its liberal structure.

\section{Evolution of Populism and Rule of Law}

The complete transformation of social polarization into political polarization is one of the structural elements and thus a critical factor of the orphan Bolivarian populism. When I use the expression "orphan populism" I mean a populist system where the figure of the charismatic and founding leader has ceased to exist. This kind of transformation concerns the profound relationship between a populist power and the social dimension, and between populist power and the consensus base.

Another important aspect of the evolution of the Venezuelan political system is also the relationship between political power and the country's institutional dimension. An evaluation of the passage from Chávez to Maduro and of the current Venezuelan political system cannot disregard the implications of the populist methods on democratic operation and on the Rule of law (Maravall and Przeworski 2003).

Bolivarian populism has profoundly changed the institutional machinery of the Venezuelan system of government. The alteration of democratic operation and of the state of law on the part of Bolivarian leadership from the first Chávez government to the current Maduro government has increased to the point that some analysts speak of a regime that is not fully democratic, but rather is a case of soft authoritarianism. That is to say, a political system with many serious issues within its democratic structure.

Venezuela has altered its normal condition of Rule of law to the point of being defined a hybrid regime, and as Levitsky and Way explain, hybrid regimes combine "democratic rules with authoritarian governance" (Levitsky and Way 2010, 51).

With the passage to Maduro's government we have a political power that first experienced a strong populist distortion and direct conditioning on the part of a charismatic leader and then, in this deformed and populist centralized system, the centralizing power was suddenly substituted by a weak, contested, and externally controlled leadership. The theme of the alteration of the Rule of Law in Venezuela is thus the theme of its political hybridization. It is a good idea to discuss some analytical elements to get an idea of this issue: the centrifugal nature of the new power, the spread of penal populism and the resistance to change.

The first point is the condition of centrifugal forces which Chavism fell into as a movement and as a de facto power after Chávez's death. This expression was used opportunely by Corrales (2013), who underlined that after Chávez's death not only was the capacity of the Chavist movement diminished to produce consensus in society, but there was also a diminishment of control within the movement and within the highest spheres of government to follow the same line. Rather, an adversarial aspect was launched in which different factions of Chavism each follow a different line and go in different directions and propose separate strategies from one another, although about general choices as electoral strategies, economic policy and foreign policy they agree. This kind of balkanization of Chavist power began 
immediately after the presidential elections of 2013 and still continues today. All you have to do in Venezuela is turn on the television to note that Chavism no longer has one person at the helm, but many figures that often have different opinions and often express divergent and even contrasting lines in different regions and in different sectors of the state. According to Corrales, the centripetal nature of the opposition contrasts with this centrifugal attitude. In my opinion this is not entirely exact. The ever more centrifugal configuration of the new Chavist power actually creates expectations of immediate change in the opposition that then finds expression in street protests; but, as the facts demonstrates, still not under a united and organized leadership. Hence, the government's external control is seen as a pretext to initiate a public action to de-legitimize the government. This short circuit is actually very dangerous because it constitutes a radicalization factor of the political conflict. On the one side, expectations of overturning the force of legitimate power are generated in the opposition camp; while on the other side, the ferment created by the protests induces a repressive behaviour ever more justified by the logic of exceptional circumstances.

Another fundamental element of political hybridization is the spread of penal populism, With Chávez, Venezuela became one of the most evident cases of Penal Populism on a global level. As John Pratt defined it, Penal Populism is the conditioning of a country's judicial system on the part of a political power (Pratt 2006). In Venezuela's case, the centralized Chavist populist power intervened on several occasions or pressured the judicial system, undermining its independence. The penal code reform of 2005, for example, is an evident demonstration of this. In this reform measures against disrespectful acts towards the government were reinforced and the use of public spaces for protests was greatly limited. Even more significant is the fact that the high positions of the Supreme Court of justice have always been assigned to men near the Chávez movement. All of this gives the measure of a Rule of Law which has been highly conditioned by political power.

After having presented these first two critical elements it would almost seem obvious to reach the conclusion that the period of Maduro's government represents a critical phase and hence of short duration. After a reflection on the passage from Chávez to Maduro, it is natural to wonder how long this kind of situation can last. On Contrary to what you might think, the problem of calculating the duration of the Chavist system is much more complex and in many respects seems to resolve itself in a scenario which is far from negative for the Bolivarians.

The fact that the government stays in place despite the reduction of consensus and growing protests indicates that the interpretation of its duration may be tied to its entrenchment in the territory according to a strategy of territorial control by Colectivos and other forms of political organization activist. Two factors explain the resilience of Maduro's government to all these critical factors, which include the economic crisis, growing violence, and social decline.

First of all, the near proximity of political power to the military apparatus. The praetorian element confers strength and resilience that other forms of political power don't have. To have it, other governments would have to make recourse to paramilitary or guerrilla formations. Military support confers the Bolivarian power with a special anchor to the territory and permits a system of control of the state 
bureaucracy both in terms of governance conditioning and in terms of clientele, since soldiers have often been used by the government for extra-military assignments such as social missions.

A second element is the theme of the durability of a revolutionary political system. Although it came to power with democratic elections, and even though the revolutionarism of the Chavist movement has always been more rhetorical than real, it is not possible to neglect this important feature of its political style. It is in fact true, that differently from Cuba, for example, Venezuela has expressed its own revolutionary objective in a constituent form, radically modifying the system of the Venezuelan state according to the objectives of Chávez's populist power. If this has avoided the use of force or the recourse to violence, it has, however, obtained similar results on the level of state and social changes, however, much in minor form.

Two political scientists, Steven Levitsky and Lucan Way, analysed the problem of the durability of revolutionary regimes, taking into consideration the political regimes of the last few centuries. As they underlined, without a doubt, revolutionary regimes characteristically last longer than other political regimes. According to these two scholars, the reasons for this peculiarity depend on four orders of factors:

1. The destruction of Independent Power Centres

2. Strong ruling party;

3. Invulnerability to Coups;

4. Enhanced coercive capacity. (Levitsky and Way 2013)

Each of these factors can be adapted to the Venezuelan case.

First of all, the destruction of independent forms of power is clear in the long process of reconverting every form of institutional power in a Chavist key. On the juridical level, the Bolivarian constitutional reform was the first act that set this dynamic in motion. The numerous actions of Bolivarian welfare, such as the social missions, have de facto taken the place of the social presence of the state. Meanwhile, from an administrative and bureaucratic point of view, the socialist party is notorious for facilitating the appointment to state jobs to those close to them.

The strength of the Partido Socialista Unido de Venezuela is demonstrated by the last 2 years of Maduro's government. In spite of the centrifugal forces and the differences among the internal factions, his government still remains firmly in place. The role of the military and militant organizations, such as the Colectivos, which often have an almost military presence in the area, help to keep this party's position strong, stronger in fact than any other party of a western liberal democracy.

As for invulnerability against coups d'état, the case of the coup of the 11th of April 2002, attempted by some sectors of the opposition and failed because of Chávez's return after 3 days, is emblematic. From that moment on, anti-coup measures on the part of Chavist governments have enormously intensified, and they also receive strategic and analytical support from Cuba and other allied countries.

Examining enhanced coercive capacity, the Chavist system has established itself throughout all the country, following a model of dominance advocated by Gramsci; 
and has developed a very strong conditioning strategy, beginning with the media and reaching significant presence in the institutions.

\section{Political Polarization}

The current crisis between the Chavist government and the opposition is too often considered in a generic manner as the expression of a political polarization that has led Venezuela to the current civil war situation. A more superficial reading could define it as the tragic epilogue of the Chavist experience. On the other hand, a more careful analysis shows that this is a process of changes that are the evolution of an ideological pattern and of political positioning of both sides, rooted in a slow and complex transformation of the Venezuelan society during the last decades. In this respect, the Chavist phenomenon, at a first stage, found the social condition for its development, but then intervened as an ideological transformative factor.

Indeed, an evolution of political polarization can be traced in Venezuela in relation to Chavism. Hellinger and Ellner's studies show how the social polarization process in this Latin American country has anticipated the process of political polarization (Ellner and Hellinger 2003). According to data from Universidad Simon Bolivar in the decade between 1988 to 1999, there has been a drastic reduction of the middle class which passed from $37 \%$ of the population to $13 \%$ in the year in which he received his first government assignment (Fig. 1).

The condition of the Chavist populist phenomenon was, therefore, an ideologization of social polarization following the neo-liberal policies of the previous decades. Social exclusion, poverty, increased crime, and growing insecurity, are all aspects of a social crisis due to the failure of a neo-liberal policy and of a corrupt democracy.

If we consider an analogous study conducted by the Universidad Simón Bolívar of Caracas (Fig. 2) on poverty trends during the second half of the nineties up to the year 2014, an interesting evolution of the phenomenon emerges. The first years of the Chávez government see a decrease in poverty which remains stable for the duration of his life at around 8,000,000 poor people. Then almost immediately after his death poverty rates rise and double within the year. This diagram clearly shows how Venezuelan society is returning to the crisis levels of the pre Chávez era from the point of view of basic social conditions.

Looking at the figures regarding the rise of poor housing, the dramatic transformation of the Venezuelan society from the eighties to Chávez's arrival is evident. In 1979, The Venezuelan National Institute of Statistics had about 18,000 poor housing cases throughout the Venezuelan territory, while it was estimated that a few years before the first government, there were more than 60,000 poor dwellings.

Another equally indicative factor of the incredible impoverishment process in the decade before the advent of Chavism is the exponential increase in murders reported on Venezuelan soil. Again, according to national statistics, about 1700 murders were declared in 1980 and more than 4500 murders in 1995. Although there is no 


\section{Social classes in Venezuela (1989)}

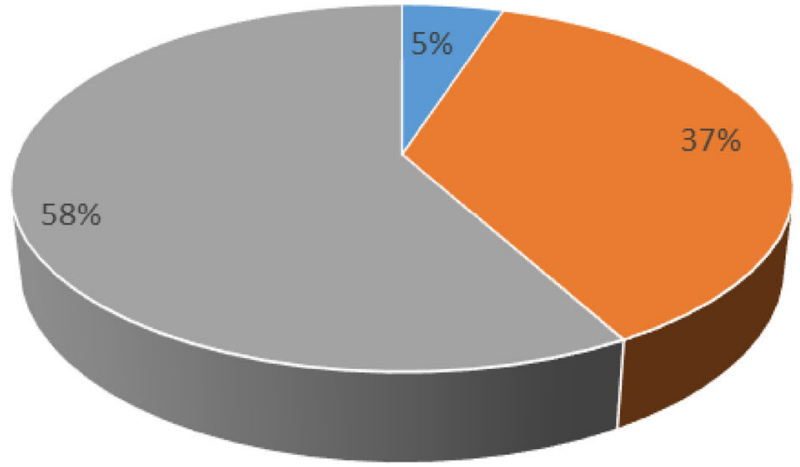

- High class - Middle class " Popular class

\section{Social classes in Venezuela (1999)}

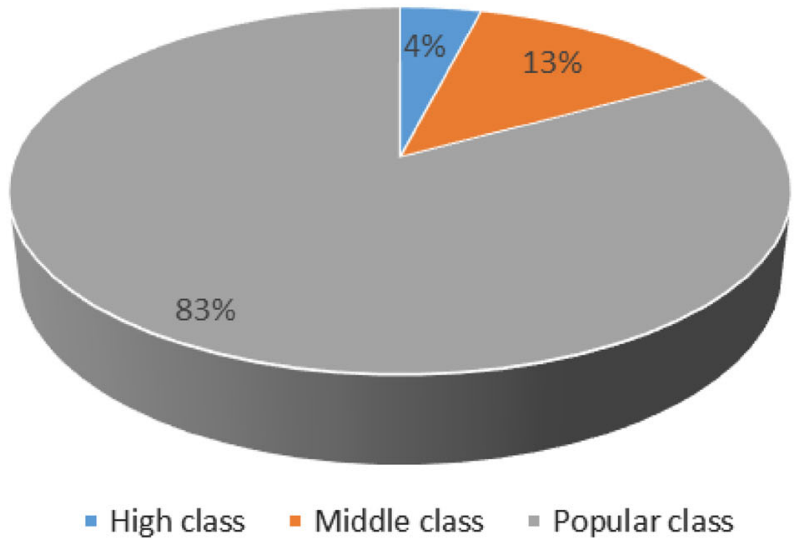

Fig. 1 Source: Universidad Simon Bolivar

accurate data, many partial sources suggest that in the following years the numbers had risen.

These are, therefore, the critical social conditions that allowed Chavism to spread and to realise that populist strategy, to say it as Kurt Weyland, based on a strong Manichean opposition: we against them (Weyland 2001). The early years of the Chavist government are characterized by an exasperation of political polarization and by strengthening the practices of contrast between the government and the opposition (Fig. 3). This has led to an exasperation of democratic dialectics and a progressive reduction in the areas of political mediation between opposing political forces. The analysis of the discursive strategies of Chavists in the propaganda of these years demonstrates how the populist phenomenon has fuelled polarization to 
Personas en Situación de Pobreza (Línea) 1989-2014

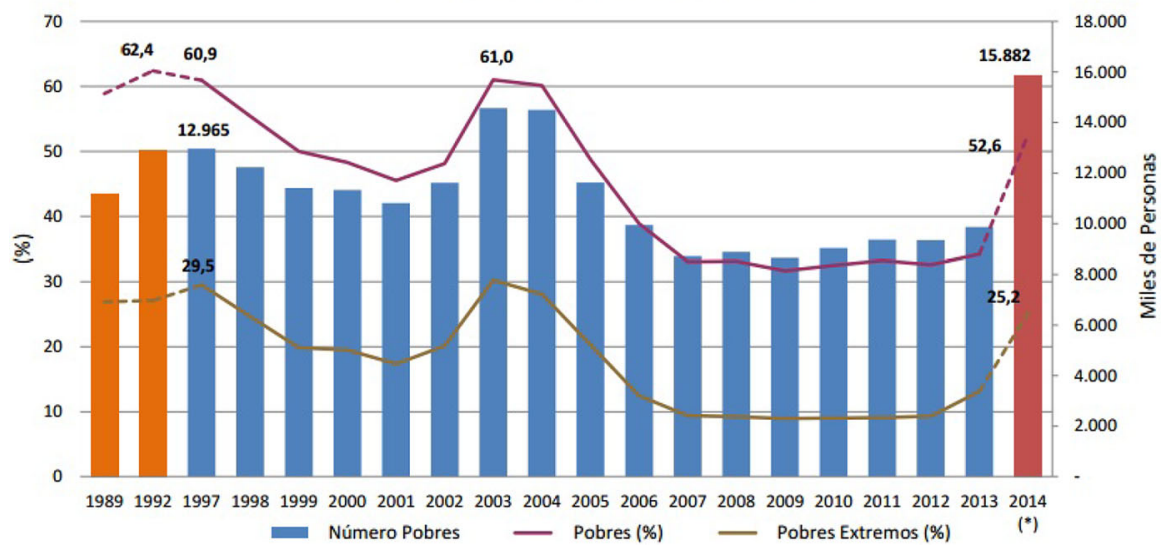

Fig. 2 Source: Universidad Simon Bolivar

Crime rates (1998-2013)

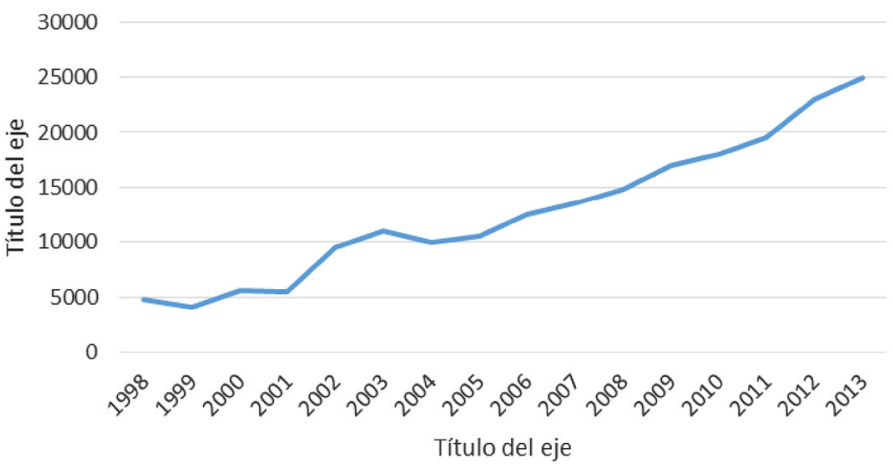

Fig. 3 Source: Universidad Simon Bolivar

reinforce the Manichaean prospect needed by populism, transforming opposition into an internal enemy to be totally eliminated. And not recognizing it as an opponent to be respected and to be confronted dialectically.

A balance of the Chavistic political polarization dynamics, however, cannot take into account the epilogue of the recent years after Chávez's death in March 2013. It is interesting to note that the leader's death has led to a further and almost fatal exasperation of political polarization, completely eliminating every possible form of mediation between the two political factions and creating in effects the conditions of confrontation similar to those of a civil war.

The first presidential election after the death of Chávez saw the victory of the designated heir Nicolas Maduro with only 400,000 votes more than the opposition candidate Capriles. This is a result that underlines the important role played by Chávez's charismatic leadership in ensuring not only its preponderance over the 
other side, but also in ensuring a conflict mediation. Chávez's death, the sudden collapse of the Chavist consensus and the subsequent strengthening of the opposition, have in fact exacerbated polarization by creating two opposing blocks without any possibility of mediation, with a very high chance of a total clash.

On this aspect the effect of polarization typical of any populism plays a fundamental role in the citizens' political participation. In particular, political polarization transforms the political opponent in an internal enemy against whom it is necessary to act for the sake of the country's safety. The potential victory of the opponent is perceived as a potential elimination of one's own side, therefore, the mobilization always acquires an emergency character. Political polarization plays a decisive role in mobilization processes, accelerating them and generating a call to an extraordinary commitment, but also transforms the political competition, increasing its conflicts and eliminating possibilities for mediation and constructive dialogue. Polarization generates a widespread commitment, which is sectarian and constantly aimed at demonizing the other side, something very different from constructive and responsible participation on the part of citizens.

If at a formal and communicative level the Manichean configuration of populism is easy to identify, recognizing the social conditions that create this peculiarity proves more difficult. Populism almost aggravates the Schmittian nature of politics, radicalising the friend-enemy relationship and limiting, on the other hand, the possibility of a constructive political dialogue among opponents. One of the social reasons behind this is the social and political polarization present in the context where populism emerges. From this point of view, the communicative structure is determined by the social structure. In this respect, Venezuela is an emblematic case, where a process of social polarization paved the way for the success of Chávez's populism.

\section{Collateral Institutionality}

Corrales and Hidalgo, both political experts, have defined Chavist Venezuela as a hybrid regime, that is to say, a form of soft authoritarianism, because it is not an entirely liberal democracy or an entirely proclaimed authoritarianism. This particular regime was defined by Morlino:

«Such a regime does not fulfil the minimalist requirements of a democracy, such as: (a) universal suffrage, both male and female; (b) free, competitive, recurrent, and fair elections; (c) more than one party; and (d) different and alternative media sources. One important aspect of this definition is that in the absence of just one of these requirements, or if at some point one of them is no longer met, there is no longer a democratic regime, but another political and institutional setup marked by varying degrees of uncertainty and ambiguity. (Morlino 2011, 2).

Transforming a liberal democracy into a hybrid regime is a de-democratization process in which the liberal democratic political regime loses some of its features. We can also call this process democratic hybridization, because it consists in the 
progressive acquisition of authoritarian elements, often not evident or proclaimed, remaining hidden from the acknowledged democratic elements of the system.

In Venezuela's case, the hybridization process consisted of a gradual transition from a liberal democracy based on two major parties and many smaller parties of moderate orientation, to a plebiscite presidential system that produced a social system parallel to the institutional one, aimed at the production and maintenance of consent. What has been a simple project to build a new welfare for the people, has become the realization of collateral institutionality. From the start, Chavism has developed social programmes and new social intervention activities such as Misiones, Bolivarian schools or Bolivarian Circulos, which then became Colectivos, which had a twofold purpose: on one hand to develop social inclusion and diminish social inequalities, and on the other, to consolidate and strengthen political consensus beyond institutional channels.

This system of extra-institutional devices can be termed as "collateral institutionality", or as Francesca Pismataro called it "parallel institutionality" and was the main factor in the hybridization of the Venezuelan democratic system (Pismataro 2016). Collateral institutionality has established direct governmental mechanisms between governor and governed, between leader and the people, removing the function of mediation and representation in the institutional body. Collateral institutionalism has weakened the check and balance mechanisms, Rule of Law, and responsiveness, that are the basis of democracy. The consensual instance prevailed over respect for institutional functionality and responsibility, demagogic pressure has in fact undermined the normal logic behind the institutions and their relationship with citizens.

Chávez's hyper-presidentialism in direct contact with the social base through collateral institutionality facilitated the realization of the main features of the Venezuelan hybrid regime: a de-legitimization of state systems; the annihilation of inter-institutional accountability mechanisms and mutual control among the various institutional sectors; the concentration of power in the hands of an executive; an uncontrolled increase in administrative and state expenses.

Inter-institutional accountability indicates the relationship between institutions. Does populism increase this kind of responsibility? Or does it diminish it, to the point of erasing it, because of a charismatic leadership that always intervenes, altering the normal relations between the institutional bodies of the state? In the case of Chávez's populisms, but also in Putin's Russia and Erdogan's Turkey, populist hyper-presidentialism has changed the usual restrictions and institutional relations between the bodies of the state, due to frequent interventions on specific issues on the part of the president.

If the constitutional reform of 1999 promoted by Chávez laid the foundations for a new plebiscitary system of the Venezuelan government system, insisting on the direct participatory aspects, on the direct link between the president and the people; the development of parallel institutionality strengthened these aspects also outside of the institutional political system, shaping a public sphere on the basis of logic of direct and non-mediated consensus.

It is interesting to note that Maduro's recent proposal for a new constitutional reform that gives greater power to Colectivos and territorial bodies goes in the 
direction of strengthening the structures of collateralization as a counterweight to the institutional crisis in an attempt to maintain hegemonic control of the country.

\section{Militarization of Political Participation and Entrenchment of Chavism}

In parallel with collateral institutionality, from the very beginning Chavism has developed a special form of political participation strongly conditioned by the Praetorian style that characterizes this movement. In fact, Chavism has created forms of territorial control very similar to those in the military world, with small squadrons of militants who preside portions of territory that were initially called Circulos bolivarianos and are nowadays called Colectivos. These groups were born to support the hegemonic tension of the revolutionary Bolivarian ideology, whose purpose was to bring the socialist democratic revolution on the one hand, and to form the new socialist man on the other, according to the dictates of the Marxist and Gramscian doctrine (Anselmi 2013) Last but not least, is the anti-coup purpose with which this kind of organization scheme has been conceived. A feature that has proved particularly useful during the 2002 coup, allowing to mobilize many people in favour of President Chávez and against the coup opposition in a very short space of time.

Considered together, the Colectivos form a network of listening, monitoring and intervention of the Chavist system, consisting of small cells, each coordinated by a leader who interfaces with the higher levels.

This network ensures an effective rooting of Chavism and demonstrates the resilience that has allowed to resist the attacks of the opposition over the last few years.

It is also possible to recognise a further hybridization factor of Venezuelan democracy in paramilitary and Praetorian functionalities of this network: the deformation of normal liberal political participation mechanisms. In this perspective, the citizen who participates in political activities becomes a semi-soldier with the responsibility for a collective action that is far more than just militant activity. On the other hand, as far as the other citizens are concerned, this network is a kind of soft threat and warning of the presidential plebiscite power.

\section{Conclusions}

In this article, I wanted to examine some structural aspects of the passage of the Bolivarian political system with Chávez to the post Chávez one governed by Maduro. I have particularly dwelt on two aspects: social dynamics the evolution of social polarization and political polarization and the transformation of the Rule of Law.

We may, therefore, conclude that when Chávez came to power, Venezuela was socially polarized, and this very polarization helped to form and consolidate the Chavist populist power. This social polarization remains with Maduro, but now it is 
the basis of a political polarization that is expressed in parliamentary representation and in the ideological polarization of Venezuelan public opinion.

If we instead consider the impact of the country's institutional system, it is interesting to reflect upon the alteration of the Rule of Law and the progressive political hybridization of the country to the point of it having been defined as a hybrid regime.

The critical scenario could make us think of a system on the brink of crisis, and yet another less evident aspect must be taken into consideration: the durability of a revolutionary government, though non violent. Its territorial entrenchment, the organizational capacities of Chavism and its hegemonic dimension makes up a strong element of resistance to the critical situation, making the entire situation more complex.

In this paper, I proposed to examine some of the key aspects of the Chavist political system following Chávez's death. After providing a synthesis of the parable Venezuelan populism in the Latin American context, my focus is particularly aimed on the process of de-democratization or hybridization of the Venezuelan political system, as a democracy that loses its functional characteristics. In particular, I have analysed some factors such as the decline of the Rule of Law, the Venezuelan post-populist conditions, political polarization, collateral institutionality, and the roots of Chávez forces.

Clearly, Chavist populism is, on the one hand, a paradigmatic case that anticipates many dynamics that will be found in other populisms, in governments also outside Latin America. But it is also a case sui generis because it is a populism that ends up being an institutionalized populist system without a populist leader, and hence it is somewhat an orphan. The factors highlighted show how populism in the government has become a presidential and plebiscitary system in which a direct power scheme from the top down has imposed exaggerating the classical democratic functioning.

Two factors, in fact, have contributed to the transformation of Venezuelan democracy into a hybrid regime: political polarization and the creation of a collateral institutionality, an alternative in comparison to what was written in the constitution.

Political polarization has facilitated the spread of a Manichean vision of politics, in which the relationship between government and opposition does not consider any mediation, but only the dominance of one party over the other. It is interesting to note that political polarization comes after a social polarization created by the fall of the neo-liberal policies of the political system before Chávez. As long as he lived, Chávez guaranteed a form of mediation between opposition and government. After his death, with the reduction of Maduro's consensus in the presidential election, polarization became radicalised, reaching the point of feeding an unsustainable situation of an almost civil war. In fact, this extreme political polarization has contributed to the elimination of all types of democratic dialectics between opposition and government, producing a kind of permanent standing war where one party sees the other, not as an opponent which has a role in the democratic system, but as an enemy to be eliminated. 
Collateral institutionality is another significant phenomenon of the process of democratic hybridization or de-democratization of the Venezuelan democratic system. In fact, it has contributed to the creation of a direct and alternative scheme of power and government to that of classical institutions, producing the effect of emptying them of their functions. Collateral institutionality has, in fact, created a plebiscite system parallel to that of a democratic state based on institutional mediation, on checks and balances, but above all, on a free and democratic political participation of citizens. This latter aspect is perhaps the most important of the Venezuelan plebiscite configuration because it provides a militant social base that is organized and acts more like a guerrilla formation rather than free participation.

On this last point, the aspect of the paramilitary configuration of Chavist forces is clarifying, these, right from the beginning, from the time of the Bolivarianos Circles until the recent Colectivos, established their presence on the territory, based on the hegemonic presidency and absolute territorial control. This special system, more like the distribution of an army, or guerrilla training, than a democratic political organization, has the advantage of ensuring a particularly strong rooting in the territory and a special resilience. This resilience in part explains the extraordinary tenacity of Chavism even without a leader. In addition, this tenancy has been particularly evident since 2014, since the opposition launched a new strategy of attack based on social protests and the use of urban violence.

Considered all together and in the developments that have followed from the beginning of this reality in 1999 to date, these structural aspects of Chavism, explain the transition from a liberal democratic system to a hybrid regime. They are also a paradigmatic example of what can happen in a strongly institutionalized populism, which goes to the government and that overrides the constitutional system and its functioning. Polarization, which at first is social, then becomes political, in the final stage becomes geopolitical. The current contrast between the government and the opposition has taken on a value that goes beyond national boundaries and points to an international opposition in which, on one side, has the sphere of influence of the United States, including Spain and England, and on the other.

\section{References}

Anselmi, Manuel. 2013. Chavez's children: Ideology, education, and society in Latin America. Maryland: Lexington Books.

Cameron, Maxwell, and Eric Hershberg. 2010. Latin America's left turns: Politics, policies, and trajectories of change. Boulder: Lynne Rienner.

Carroll, Rory. 2013. Comandante. La Venezuela de Hugo Chavez. México: Sexto Piso Realidades.

Conniff, Michael. 1982. Latin American populism in comparative perspective. Albuquerque: University Mexico Press.

Conniff, Michael. 2012. Populism in Latin America. Tuscaloosa: Alabama Press.

Corrales, Javier. 2013. ¿Un Maduro Más Duro? Venezuela After Chávez. Berkeley Review of Latin American Studies: Spring.

Corrales, Javier, and Manuel Hidalgo. 2013. El régimen hibrido de Hugo Chavez en transiciòn (2009-2013). Desafíos 25 (1): 47-86. 
De La Torre, Carlos \& Cynthia J. Arnson. 2013. Latin American populism in the twenty-first century. Washington: Woodrow Wilson Center Press.

Diamond, Larry, and Leonardo Morlino. 2005. Assessing the quality of democracy. Baltimore: The Johns Hopkins University Press.

Diamond, Larry. 2002. Thinking about hybrid regimes. Journal of Democracy 13 (2): 21-35.

Ellner, Steve, and Daniel Hellinger (eds.). 2003. La política venezolana en la época de Chávez: clases, polarización y conflicto. Caracas: Nueva Sociedad Editorial.

Hawkins, Kirk A. 2010. Venezuela's Chavismo and populism in comparative perspective. Cambridge: Cambridge University Press.

Levitsky, Steven, and Lucan A. Way. 2010. Competitive authoritarianism: Hybrid regimes after the cold war. Cambridge: Cambridge University Press.

Levitsky, Steven, and Lucan A. Way. 2013. The durability of revolutionary regimes. Journal of Democracy 24 (3): 5-17.

Maravall, José María, and Adam Przeworski (eds.). 2003. Democracy and the rule of law. Cambridge: Cambridge University Press.

Morlino, Leonardo. 2011. Hybrid regimes. In Badie, Badie, Berg-Schlosser, Dirk \& Morlino, Leonardo. (eds). International encyclopedia of political science. Thousand Oaks: SAGE Publications.

Mudde, Cas \& Rovira Kaltwasser, Cristobal. 2014. Populism in Europe and the Americas: Threat or corrective for democracy? Cambridge: Cambridge University Press.

Pismataro, Francesca Ramos. 2016. La institucionalidad paralela como estrategia de acciòn gubernamental en la Venezuela Bolivariana. In De Chavez. A Maduro: Balance y Perspectivas, Pismataro Ramos, Francesca, De Lisio, Antonio, Rodriguez Ronal F. eds. Bogotá: Editorial Universidad del Rosario.

Pratt, John. 2006. Penal populism. London: Routledge.

Rouquié, Alain. 2000. L’America latina. Milano: Bruno Mondadori.

Weyland, Kurt. 2001. Clarifying a contested concept: Populism in the study of Latin American politics. Comparative Politics 34 (1): 1-22.

Manuel Anselmi is Assistant Professor of Political Sociology at University of Perugia. His area studies are Latin American Politics, Latin American Populism and Venezuelan Politics. He is author of Chavez's Children. Ideology, Education and Society in Latin America. Lexington 2013; Populism. An Introduction. Routledge (Forthcoming 2017) 